CHURCH AND ESTATE 


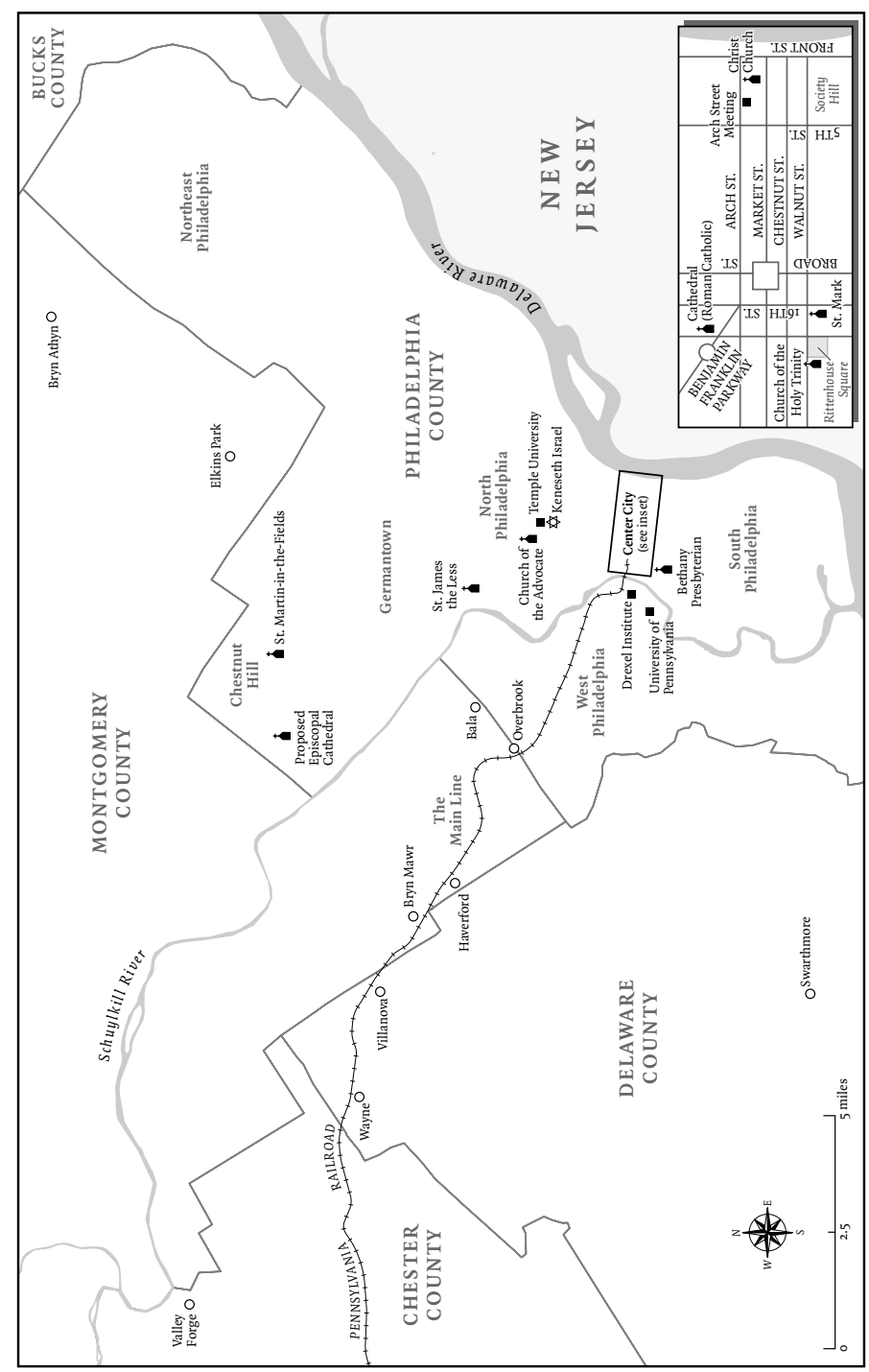


TH O M A S F. R Z E Z N I K

\title{
CHURCH AND ESTATE
}

\author{
RELIGION AND WEALTH IN \\ INDUSTRIAL-ERA PHILADELPHIA
}

The Pennsylvania State University Press

University Park, Pennsylvania 


\section{Library of Congress Cataloging-in-Publication Data \\ Rzeznik, Thomas F., 1979-}

Church and estate : religion and wealth in industrial-era Philadelphia / Thomas F. Rzeznik.

$$
\text { p. } \mathrm{cm} \text {. }
$$

Summary: "Examines the lives and religious commitments of the Philadelphia elite during the period of industrial prosperity that extended from the late nineteenth century through the 1920s"-

Provided by publisher.

Includes bibliographical references and index.

ISBN 978-0-271-05967-9 (cloth)

1. Upper class-Religious life-Pennsylvania-Philadelphia-History-19th century.

2. Upper class-Religious life-Pennsylvania-Philadelphia-History-20th century.

3. Upper class-Pennsylvania-Philadelphia-Social life and customs-19th century.

4. Upper class-Pennsylvania-Philadelphia-Social life and customs-20th century.

5. Wealth-Pennsylvania-Philadelphia-Religious aspects-Christianity.

6. Philadelphia (Pa.) - Church history-19th century.

7. Philadelphia (Pa.) - Church history-20th century.

I. Title.

BR560.P5R94 2013

305.5'2340974811-dc23

2012051317

Copyright (C) 2013 The Pennsylvania State University

All rights reserved

Printed in the United States of America

Published by The Pennsylvania State University Press, University Park, PA 16802-1003

It is the policy of The Pennsylvania State University Press to use acid-free paper. Publications on uncoated stock satisfy the minimum requirements of American National Standard for Information Sciences-Permanence of Paper for Printed Library Material, ANSI Z39.48-1992.

This book is printed on paper that contains $30 \%$ post-consumer waste. 
To my parents 
